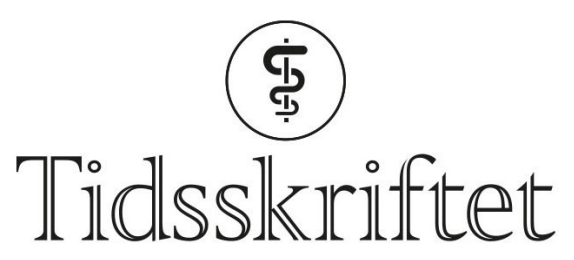

DEN NORSKE LEGEFORENING

\title{
Er det intensjonen som teller?
}

MEDISIN OG TALL

\section{MATS JULIUS STENSRUD}

E-post:m.j.stensrud@medisin.uio.no

Mats Julius Stensrud er lege og postdoktor ved Avdeling for biostatistikk, Institutt for medisinske basalfag, Universitetet i Oslo. Han er for tiden på et Fulbright-opphold ved Harvard T.H. Chan School of Public Health i USA.

Forfatteren har fylt ut ICMJE-skjemaet og oppgir følgende interessekonflikt: Hans arbeidssted har mottatt penger fra Norges forskningsråd til prosjektet «Analyzing clinical health registries: Improved software and mathematics of identifiability» (NFR239956/F20).

Et nytt medikament er tilgjengelig. Det ble testet i et randomisert kontrollert fors $ø$, som viste 3 \% bedring i femårsoverlevelse sammenlignet med et eldre medikament. Det er vanligvis underforstått at denne forskjellen er beregnet ut fra prinsippet om behandlingsintensjon (intention to treat, ITT), og mange studier rapporterer utelukkende behandlingsintensjonseffekten. Men er det bare dette effektmålet vi er interessert i?

Ideen bak behandlingsintensjonseffekten (ITT-effekten) er enkel: Vi randomiserer pasienter til forskjellige behandlinger, la oss si med et nytt og et gammelt medikament. Deretter studerer vi forskjellen i behandlingseffekt mellom de som ble randomisert til det nye medikamentet og de som ble randomisert til det gamle medikamentet (figur 1). Effektmålet er tiltalende fordi det kan tolkes kausalt, og i tillegg er det ukomplisert å beregne. 


\section{(-) Følger protokollen

\section{Randomisert til nytt medikament}

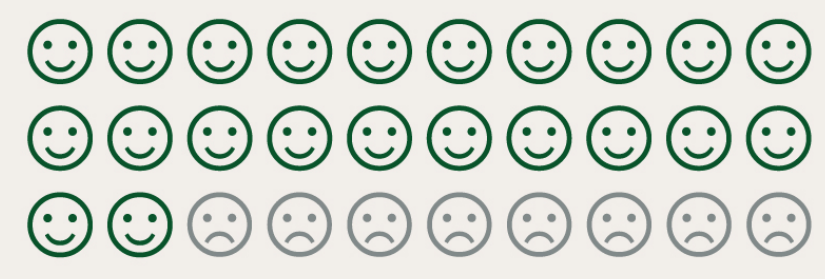

Randomisert til gammelt medikament

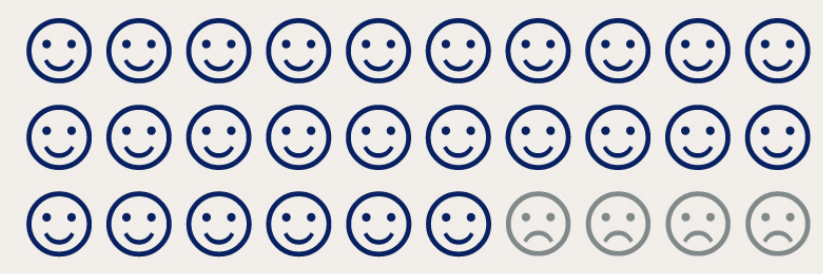

Figur 1 Hva skal vi gjøre med pasientene som ikke følger protokollen? Når vi beregner behandlingsintensjonseffekter, inkluderes disse pasientene i analysen. Når vi beregner tradisjonelle per protokoll-effekter, ekskluderes disse pasientene fra analysen.

Det er likevel viktig å forstå at behandlingsintensjonseffekten ikke måler effekten av behandlingen i seg selv, men effekten av å bli randomisert til behandling. Grunnen er at noen pasienter ikke følger behandlingsregimet de ble randomisert til. For eksempel glemmer noen pasienter å ta medisinene sine, og noen pasienter tar andre medisiner enn de som ble forskrevet. Behandlingsintensjonseffekten må derfor tolkes varsomt, spesielt i såkalte ikkeunderlegenhetsstudier (1). Anta at vi skal sammenligne to kolesterolsenkende medikamenter. Det gamle medikamentet gir en mild og ufarlig bivirkning slik at $20 \%$ ikke tar medikamentet som foreskrevet. Det nye medikamentet har ikke denne bivirkningen, og bare $10 \%$ av pasientene tar ikke dette medikamentet som foreskrevet. En randomisert studie rapporterer at det nye medikamentet ikke er underlegent etter å ha regnet ut en behandlingsintensjonseffekt. Men kanskje er effektmålet påvirket av forskjellen i etterlevelse? Hvis alle tok medikamentet som foreskrevet i hver gruppe, ville det kanskje vise seg at det gamle medikamentet er bedre enn det nye. Og hva hvis denne trivielle bivirkningen lett kan unngås med et enkelt hverdagslig tiltak?

\section{Realistisk effektmål?}

Mange mener likevel at behandlingsintensjonseffekten gir et realistisk effektmål: Vi kan ikke forvente at alle pasienter følger behandlingsplanen i en vanlig klinisk hverdag, og behandlingsintensjonseffekten «tar høyde for dette». Men selv om vi ikke forventer full etterlevelse i vanlig klinisk praksis, er ikke behandlingsintensjonseffekten nødvendigvis representativ, og den løser ikke problemene knyttet til generaliserbarhet i randomiserte kliniske studier. Tvert imot er det mange grunner til å anta at behandlingsintensjonseffekten ikke er representativ (2).

Det er også vanlig å anta at behandlingsintensjonseffekten er et konservativt effektmål. Argumentet er gjerne at den reelle effekten blir utvannet fordi noen pasienter ikke følger behandlingsplanen. Dette er antagelig riktig i mange scenarioer, men forklaringen er bare garantert å være gyldig hvis vi antar at effekten har samme retning hos alle individer. La oss si at et antikoagulerende medikament har gunstig behandlingsintensjonseffekt på 
overlevelsen til pasienter med atrieflimmer. For å hevde at effekten er konservativ, må vi egentlig anta at alle pasientene har gunstig effekt av antikoagulasjon på overlevelse. I metodelitteraturen kalles dette at effekten er monoton, og en slik monotonisitet er ikke opplagt. Blant annet er det mulig at et fåtall pasienter som får antikoagulasjonsbehandling, dør tidlig av hjerneblødning.

I de mange situasjonene hvor behandlingsintensjonseffekten er et konservativt mål, har vi likevel et problem når vi skal studere bivirkninger av medisiner, fordi vi risikerer å systematisk underestimere dem.

\section{Tolk tallene varsomt}

Hvis jeg var pasient og skulle velge mellom medikamenter, ville jeg helst ha sammenlignet et hypotetisk scenario der alle tok det nye medikamentet som foreskrevet med et annet scenario der alle tok det gamle medikamentet som foreskrevet. Problemet er selvfølgelig at det er umulig å observere slike scenarioer. I stedet har det vært vanlig å gjøre enkle per protokoll-analyser, dvs. å begrense analysen til kun å omfatte de pasientene som til enhver tid har full etterlevelse. Slike analyser er ikke ideelle fordi de rammes av seleksjonsskjevhet: Pasientene med full etterlevelse har ofte en annen sykdomsrisiko enn pasientene med manglende etterlevelse.

Den beste strategien er trolig å beregne flere effektmål og å vurdere svakhetene ved de ulike målene. Vi bruker altså flere metoder for å nærme oss det riktige svaret. Før et legemiddel får markedstillatelse, stilles det krav om at både behandlingsintensjonseffekter og per protokoll-effekter oppgis. De siste årene har det dessuten blitt utviklet flere nye statistiske metoder (kausale modeller) for å beregne per protokoll-effekter. Disse metodene krever mye sterkere antagelser enn metodene for behandlingsintensjonseffekter, men de reduserer problemene med seleksjonsskjevhet sammenlignet med tradisjonelle per protokoll-analyser (3). Etter min mening kan slike metoder gi viktig tilleggsinformasjon i mange kliniske studier.

LITTERATUR:

1. ICH Expert Working Group. ICH Harmonised Tripartite Guideline: statistical principles for clinical trials (E9). ICH, 1998.

https://www.ich.org/fileadmin/Public_Web_Site/ICH_Products/Guidelines/Efficacy/E9/Step4/E9_Gui deline.pdf(8.1.2019).

2. Hernán MA, Hernández-Díaz S. Beyond the intention-to-treat in comparative effectiveness research. Clin Trials 2012; 9: 48-55. [PubMed][CrossRef]

3. Hernán MA, Robins JM. Per-protocol analyses of pragmatic trials. N Engl J Med 2017; 377:1391-8. [PubMed][CrossRef]

Publisert: 25. mars 2019. Tidsskr Nor Legeforen. DOI: 10.4045/tidsskr.18.0956

(C) Tidsskrift for Den norske legeforening 2020. Lastet ned fra tidsskriftet.no 